\title{
Alienação no trabalho médico no enfoque da humanização-desumanização
}

\author{
Alienation in medical work in the humanization-dehumanization \\ approach
}

\author{
La alienación en el trabajo médico en el enfoque de la \\ humanización-deshumanización
}

HUMANIZAÇÃO E DESUMANIZAÇÃO NO TRABALHO EM SAÚDE. Gomes RM. Rio de Janeiro: Editora Fiocruz; 2017. 312 p. ISBN 978-857541-491-0.

doi: 10.1590/0102-311X00152118

O livro Humanização e Desumanização no Trabalho em Saúde 1 traz importante contribuição ao debate nesse campo, focando no trabalho médico e suas implicações. Reapresenta os paradoxos ou contradições na prática médica, trazendo à tona o sofisticado arsenal tecnocientífico que a impregna e as reconhecidas limitações em sua capacidade de contribuir com a produção de "vidas mais plenas de sentido para indivíduos e coletividades", como diz o autor do livro.

Assim, faz dialogar os elementos que perpassam as práticas médicas em seus modos instituídos de se configurar e, nesses modos, também estão presentes perspectivas instituintes que os confrontam.

Toma-se a alienação como categoria central, explorando a sua relação com a humanização e alertando para a abordagem dialética desses conceitos ou processos. Ao recorrer a Marx, o autor afirma a alienação a partir das relações sociais de produção em contextos históricos, e aí está inserida a prática médica, entre o humanizado e suas múltiplas formas de alienação/desumanização. Compõe uma equação que agrega âmbitos de mudanças político-econômico-sociais e aspectos do trabalho médico, pondo em correlação as transformações nos perfis de adoecimento, com novos padrões epidemiológicos e novas necessidades em saúde; expansão do acesso a serviços e a informações científicas; reestruturação produtiva, com progressiva incorporação tecnológica e farmacomedicalização, bem como reestruturação de todo o complexo médico-industrialfinanceiro indutor de novos comportamentos profissionais e de mudanças no sistema sanitário; fragmentação do objeto de trabalho médico, agravada com a intensificação da divisão técnica e organizativa do sistema assistencial.

Nesse contexto e em meio a novas necessidades, os médicos veem-se confrontados com exigências, limitações e pressões por novos tipos de "entradas" ou de intervenções que passam a lhes caber ou mesmo a lhes serem impostas na prática assistencial.

Com as alterações no sistema produtivo e nos processos de trabalho, os recursos tecnológicos e organizacionais passam a disputar a centralidade no cenário assistencial e induzem a mecanização da atividade médica. A subordinação a esses recursos, com a reificação dos meios de trabalho, opera-se em um processo de competição com os outros recursos próprios à prática médica: seu saber da experiência, vindo do trabalho vivo.

Aponta-se também a dependência de empresas de seguros-saúde e a institucionalização do trabalho médico, expropriando-se sua condição de agente no processo produtivo, exacerbando o 
grau de heterocontrole de sua prática. Complementa e agrava esse quadro a divisão técnica e social, na qual se cruzam o peso das tecnologias e da tendência à especialização, reduzindo o objeto de trabalho (sua "dimensão reflexiva e integral") e também a capacidade de abordar o processo de adoecimento à luz de fatores que não os da esfera biológica.

Um dos vetores de efeitos alienantes nesse contexto expressa-se na expectativa de êxito e eficiência do trabalho médico, vivendo-se em um desequilíbrio entre necessidades, demandas e interesses do entorno: seu foco de interesse (dos médicos) em relação aos objetos e produtos de sua atividade, as imposições do sistema socioeconômico, a institucionalização do trabalho e as expectativas dos usuários, não só de satisfação de suas necessidades de bem-estar ou de "saúde", mas também as pressões que hoje exercem ao terem se tornado (também) consumidores de procedimentos. Tornam-se interesses conflitantes, que não só escapam ao controle médico como também não compõem seu âmbito de reflexão, aspecto especialmente definidor da condição de alienação. A alienação, portanto, é condicionada a um âmbito de sobreimplicação ${ }^{2}$, pela própria dificuldade de compreender os interesses mercantis e expectativas que estão no entorno da sua prática, nesse caso inscrita como qualquer outra na esfera das relações sociais de produção. Não é demais reforçar as análises históricas que se resgatam, marcando a importância do setor saúde no sistema capitalista de reprodução da força de trabalho.

Em um vetor associado ao vínculo médicopaciente, uma importante alteração (entendida como desumanização) decorre da condição anterior de médico artesão e liberal para uma condição de profissional institucionalizado e guiado por protocolos, em um agir marcado pela impessoalidade e que abala a relação de confiança, antes dada pelo vínculo direto entre usuário e profissional. As novas condições de encontro médico-paciente são marcadas por restrições de tempo, interações condicionadas à institucionalização e tecnologização do trabalho e comprometimento comunicacional entre esses dois sujeitos. No rastro desses (des)encontros, surgem novas significações que os próprios médicos passam a dar ao seu trabalho, além de novas representações sociais que se constituem acerca de seu papel.

Eis aqui elementos cruzados na análise do autor e o caminho que vai explicitando a produção da alienação-desumanização. Manifestações típicas desse processo expressam-se no predomínio de uma ação mais instrumental e fragmentada, não na lógica do cuidado singularizado. Além disso, a prática é carregada de excessos (de fármacos, exames, procedimentos, prescrições de modos corretos de viver etc.) condicionados às pressões do modelo vigente e carregada de prescrições morais travestidas de neutralidade. Essas práticas são insuficientes para satisfazer as necessidades dos usuários e geram insatisfação mútua. Por outro lado, fragilizam-se os vínculos afetivos com o trabalho, o que resulta em sentimentos (e sintomas) associados à perda de autonomia e protagonismo.

A alienação expressa-se, então, em múltiplas dificuldades, superpondo-se: a própria condição de subordinação ou expropriação do controle de sua atividade, a falta de reflexão sobre isso, a negação das situações a que se está exposto e a incapacidade ou baixa capacidade de se reagir a elas.

Entretanto, é também nesse mesmo contexto que se observam os sinais de resistência ao instituído do momento. Em diálogo com o autor, falaríamos em perspectivas instituintes, ilustradas nos depoimentos médicos que, nesse cenário de pressões e exposições a um importante quantum de determinantes externos e prescrições, vislumbram também novas formas de agir, criando oportunidades para novas práticas. Em outros termos, e acompanhando estudiosos do trabalho como atividade 3,4 , falaríamos sobre a capacidade de (re)invenção que se coloca em ato nesses contextos adversos, fazendo crescer o potencial de agir. A própria presença dos recursos tecnológicos e de padronização tem força para alijar o saber profissional imanente à experiência e ao trabalho vivo, mas também se efetiva com valor de uso a ele articulado quando contribui para aumentar a capacidade de intervenção sobre problemas e a serviço do cuidado. Aqui muito importa esse destaque porque os pressupostos 
ético-estético-políticos da humanização (no referencial da Política Nacional de Humanização $\mathrm{PNH}$ ) sustentam inovações nos modos de gerir e de cuidar em saúde, aumentando-se a capacidade de análise e de intervenção dos sujeitos/coletivos em suas realidades de trabalho e por meio de deslocamentos em suas próprias subjetividades 5,6,7. Nesse rumo, a perspectiva da humanização não deixa margem para idealização dos sujeitos, processos de trabalho e relações de produção, nem para negação de elementos, inclusive tecnológicos, que não se impõem de sentido em si mesmos e que não se estabelecem isoladamente, mas que devem ser vistos nas interconexões que podem se dar em umas e outras direções, a depender dos agenciamentos de projetos coletivos produzidos. Por isso, vale destacar o que também atesta o autor, ao tratar da inquestionável contribuição da tecnologia e de sua interferência positiva na resolução de problemas, respondendo qualitativa e quantitativamente a muitas necessidades. O que se põe em análise são as contradições que vêm em seu bojo, ajudando a ampliar e complexificar horizontes de intervenções e, ao mesmo tempo, induzindo o profissional a reduzir e constringir seu trabalho.

$\mathrm{Na}$ análise do autor, assim se opera a medicina atual: entre um "tanto" de humanização e também de desumanização. E entre suas várias repercussões, destacam-se as manifestações de sofrimento e desgaste que acompanham os profissionais em sua alienação. Vale enfatizar que não por acaso a PNH prioriza em seu arcabouço aquilo que diz da relação trabalho e subjetivida- de, por aí convidando a se compreender a estreita interface entre dor-sofrimento-prazer no trabalho e os modos como se vive e como se pode re-existir no mundo da vida e do trabalho 8 .

\section{Serafim Barbosa Santos Filho 1,2}

${ }^{1}$ Ministério da Saúde, Belo Horizonte, Brasil.

2 Escola de Enfermagem, Universidade Federal de Minas

Gerais, Belo Horizonte, Brasil.

serafimsantos@terra.com.br

1. Gomes RM. Humanização e desumanização no trabalho em saúde. Rio de Janeiro: Editora Fiocruz; 2017.

2. Altoé $\mathrm{S}$. Renè Lourau: analista institucional em tempo integral. São Paulo: Editora Hucitec; 2004.

3. Clot Y. Trabalho e poder de agir. Belo Horizonte: Fabrefactum; 2010.

4. Schwartz Y, Durrive L. Trabalho e ergologia. Niterói: Eduff; 2010.

5. Benevides R, Passos E. Humanização na saúde: um novo modismo? Interface Comun Saúde Educ 2005; 9:389-94.

6. Santos Filho SB, Barros MEB, Gomes RS. A Política Nacional de Humanização como política que se faz no processo de trabalho em saúde. Interface Comun Saúde Educ 2009; 13:603-13.

7. Guattari F. Revolução molecular. São Paulo: Brasiliense; 1981.

8. Santos Filho SB, Barros MEB. Trabalhador da saúde: muito prazer - protagonismo dos trabalhadores na gestão do trabalho em saúde. Ijuí: Editora Unijuí; 2009. 